Int. J. Electrochem. Sci., 15 (2020) $311-318$

\title{
N719-Dye Based Electrochemical Light and Temperature Sensor
}

\author{
Asma Khalil ${ }^{1,2}$, Zubair Ahmad ${ }^{3}$, Farid Touati $^{1}$ and Mohamed Masmoudi ${ }^{2}$ \\ ${ }^{1}$ Department of Electrical Engineering, Qatar University, 2713, Doha Qatar \\ ${ }^{2}$ Department of Electrical Engineering, National Engineering School of Sfax, Sfax 3038, Tunisia \\ ${ }^{3}$ Center for Advanced Materials (CAM), Qatar University, 2713, Doha Qatar \\ *E-mail; zubairtarar@qu.edu.qa
}

doi: $10.20964 / 2020.01 .36$

Received: 2 Sepember 2019 / Accepted: 22 October 2019 / Published: 30 November 2019

In this article, electrochemical N719-Dye based integrated light and temperature sensors have been reported. The fabricated sensor exhibits interesting features such as low cost, simple fabrication process, high sensitivity and self-powering capability. Current-Voltage (I-V) and Electrochemical Impedance Spectroscopy (EIS) characterizations have been performed to study the electrical and photo-electrochemical response of the sensors. The electrochemical response has been investigated as a function of incident light intensity and temperature. The sensors show a linear current-irradiance and current-temperature relationships. The transient response and recovery times of the photo sensors are $220 \mathrm{msec}$ and $630 \mathrm{msec}$, respectively. The measured sensor's responsivity is $3 \times 10^{-4} \mathrm{~A} / \mathrm{W}$ while its sensitivity is $7 \mu \mathrm{S} . \mathrm{m} . \mathrm{W}^{-1}$. The above results make the newly proposed integrated light and temperature sensor very promising and pave the way for the development of simple and cost effective light and temperature sensors.

Keywords: Electrochemical cell, Dye Sensitized Solar Cell, Light sensor, Temperature sensor, electrochemical Impedance Spectroscopy.

\section{FULL TEXT}

(C) 2020 The Authors. Published by ESG (www.electrochemsci.org). This article is an open access article distributed under the terms and conditions of the Creative Commons Attribution license (http://creativecommons.org/licenses/by/4.0/). 